\title{
PERLINDUNGAN HUKUM TERHADAP PETANI PENGGARAP TANAH NEGARA MILIK PERUM PERHUTANI
}

\author{
Iwan Permadi \\ Fakultas Hukum Universitas Brawijaya \\ J1. MT. Haryono No. 169 Malang \\ Email:permadi_iwan@yahoo.com
}

\begin{abstract}
This paper aims to analyze the legal implications of farmers that are not allowed to work on public land controlled by Perum Perhutani which causes conflicts, especially on land abandoned by Perum Perhutani and determine the form of legal protection against farmers who work the state land ruled by Perhutani to prevent horizontal conflicts between society and Perhutani. The author uses the normative method that is supported by empirical data. Farmers are not allowed to work on land controlled by perhutani because it is considered by Perhutani to be State Land, wherea from the law perspective if the land controlled by Perhutani is abandoned the it becomes free state land that is not entitled. Forms of legal protection against Farmers who work the land ruled by Perhutani state is through preventive and repressive legal protection, namely through the issuance of land titles to the land controlled by the Perhutani but abandoned by Perhutani.
\end{abstract}

Key words: legal protection, farmer, land controlled by Perhutani

\begin{abstract}
Abstrak
Tulisan ini bertujuan untuk menganalisis implikasi hukum petani tidak diperbolehkan menggarap tanah negara yang dikuasai oleh Perum Perhutani yang mengakibatkan konflik khususnya pada tanah yang ditelantarkan oleh Perum Perhutani dan mengetahui bentuk perlindungan hukum terhadap Petani yang menggarap tanah negara yang dikuasai oleh Perhutani agar tidak terjadi konflik horizontal antara masyarakat dan Perhutani. Penulis menggunakan metode yuridis normatif yang didukung dengan data empirik. Petani tidak diperbolehkan menggarap tanah yang dikuasai perhutani karena dianggap oleh Perhutani itu adalah Tanah Negara, padahal secara hukum apabila tanah yang dikuasai oleh Perhutani tersebut ditelantarkan maka akan menjadi tanah Negara bebas yang tidak mempunyai alas hak. Bentuk perlindungan hukum terhadap Petani yang menggarap tanah negara yang dikuasai oleh Perhutani adalah melalui perlindungan hukum preventif dan represif, yaitu melalui pemberian hak atas tanah terhadap tanah yang dikuasai oleh Perhutani tersebut tetapi ditelantarkan oleh Perhutani.
\end{abstract}

Kata kunci: perlindungan hukum, petani, tanah yang dikuasai Perhutani

\section{Latar Belakang}

Tanah adalah aset yang paling penting dalam kehidupan masyarakat karena tanah adalah sumber kehidupan. Dalam negara agraris tanah merupakan sumber utama dalam berproduksi sehingga di Indonesia dalam hak kepemilikan, hak guna usaha, hak pakai, hak sewa, hak membuka tanah, hak memungut 
hasil hutan dibatasi dalam Undang-Undang Pokok Agraria. Sebagian besar petani di Indonesia adalah buruh tani dan petani gurem atau sering disebut sebagai Peasant bukan farmer. ${ }^{1}$ Permasalahan mengenai pertanahan bisa menimbulkan konflik yang berkepanjangan antara orang dengan orang maupun orang dengan badan hukum. Sengketa pertanahan ini muncul karena kebutuhan manusia akan tanah selalu bertambah seiring dengan pertambahan penduduk. Hal tersebut melahirkan paradigma bahwa kebutuhan akan tanah pertanian bagi petani pada saat ini sangatlah mendesak. Sementara banyak tanah nganggur (terlantar) yang tidak digarap adalah sebuah keniscayaan bagi petani yang tidak mempunyai tanah garapan terutama pada tanah-tanah yang dikuasai oleh Perum Perhutani.

Petani lokal yang berdomisili di tepian hutan, memandang bahwa secara tradisional yang ada di kawasan itu merupakan sumber penghidupan, cadangan perluasan tanah garapan, dan sekaligus sebagai daerah food security. Bagi penduduk lokal, gangguan ekologi yang datang dari luar hutan akan mengancam kehidupan sosial dan ekonomi mereka. Sementara perusahaan pemegang hak penguasaan hutan memandang bahwa kawasan hutan merupakan tanah yang secara legal telah dikuasakan negara kepadanya untuk dikelola secara komersial dengan tujuan mendapatkan keuntungan yang sebesar-besarnya. Persoalan sosial tersebut yang menyebabkan konflik yang dapat mengancam harmonisasi sosial. ${ }^{2}$

Otoritas penguasaan dan pengelolaann sumber daya hutan diberikan kepada Perum Perhutani berdasarkan Undang-undang No. 41 Tahun 1999 tentang Kehutanan (selanjutnya disebut UU Kehutanan), dimana Perum Perhutani merupakan Badan Usaha Milik Negara (BUMN) yang berada di bawah Kementerian Kehutanan. Hak yang dimiliki Perum Perhutani atas sumber daya hutan adalah hak pengelolaan yang berasal dari hak menguasai negara melalui tiga peran pokok, yaitu sebagai penguasa tanah hutan, perusahaan kehutanan (forest enterprise) dan institusi konservasi hutan (forest conservation institution). Konsekuensi yuridis yang muncul adalah petani yang menggarap tanah (termasuk memanfaatkan hasil hutan) seringkali menimbulkan konflik tanah kawasan hutan di beberapa daerah ${ }^{3}$.

Salah satu contoh tanah yang nganggur (terlantar) tersebut adalah tanah yang dikuasai oleh Perhutani dan dikerjakan atau digarap langsung oleh Petani di Kabupaten Pati yang ijin menggarapnya ditolak oleh Perum Perhutani. Para petani di Kabupaten Pati Jawa Tengah harus rela melakukan perlawanan hanya untuk sebuah

1 Noertjahyo, JA., Dari Ladang Sampai Kabinet, Menggugat Nasib Petani, (Jakarta: Buku Kompas, 2005), hlm. 14.

2 Abu Rokhmad, "Petani vs Negara: Studi tentang Konflik Tanah Hutan Negara dan Resolusinya dalam Perspektif Fiqh", Makalah Annual Conference on Islamic Studies, http://arifrohmansocialworker.co.id, diakses 12 Maret 2016.

3 Ibid. 
tanah garapan. Banyak petani di Indonesia kekurangan tanah garapan. Sementara janji Presiden Jokowi akan memberikan tanah garapan untuk petani belum dipenuhi dan masyarakat bawah khususnya petani seperti di Kabupaten Pati harus memperjuangkan nasibnya berjuang untuk memperoleh tanah garapan. Para petani tentu akan menagih janji Presiden yang akan memberikan jutaan tanah garapan bagi petani yang belum punya tanah garapan. Di Kabupaten Pati, banyak tanah nganggur (terlantar) yang dikuasai Perum Perhutani KPH Pati yang bisa digarap oleh petani, namun realita yang terjadi justru pihak Perhutani KPH Pati menjadi penyebab konflik dengan petani sekitar hutan. ${ }^{4}$

Tanah yang dikuasai Perhutani KPH Pati misalnya, terdapat ratusan hektar tanah yang nganggur dan tidak tergarap. Namun ironisnya petani harus bersaing dengan para pemilik modal yang bisa dengan mudahnya menyewa tanah tersebut. Akibatnya petani semakin termarjinalkan. Contoh lain adalah tentang kasus sengketa tanah antara petani dan Perum Perhutani yang ada di Desa Genteng, Kecamatan Sukasari, Kabupaten Sumedang. Mayoritas mata pencaharian masyarakat Desa Genteng adalah bertani. Layaknya seorang petani untuk meningkatkan perekonomiannya, maka tanah sangat dibutuhkan. Begitu juga dengan petani di Desa Genteng, mereka juga butuh tanah untuk dikelola. Bukan hanya tanah saja yang mereka butuhkan, modal, teknologi juga mereka butuhkan ${ }^{5}$.

SengketatanahyangterjadidiDesaGenteng antara petani dan Perum Perhutani terjadi karena pendudukan tanah yang dilakukan oleh petani di tanah Perhutani. Masyarakat yang membutuhkan tanah memanfaatkan tanah dari Perhutani. Sementara Perhutani ingin melakukan konservasi hutan agar sumber airnya tidak kekeringan. Musyawarah yang dilakukan belum menemukan solusi sehingga sengketa tanah tersebut diajukan pada Pemerintah Kabupaten Sumedang. Bagi masyarakat petani Desa Genteng jaminan atas tanah tertuang dalam Undang-Undang No. 5 Tahun 1960 tentang Pokok-Pokok Agraria (selanjutnya disebut UU Pokok Agraria). Undang-undang ini dibuat untuk mengatur mengenai hak-hak pertanahan bagi masyarakat Indonesia secara menyeluruh. Di lain pihak UU Kehutanan merupakan salah bentuk jaminan bagi Perhutani untuk melakukan konservasi hutan. Hal ini membuat banyak petani Desa Genteng tergusur dari tanah yang sedang dia kelola untuk menyambung hidup. Dari contoh-contoh kasus sengketa diatas, maka perlu dipikirkan bagaimana bentuk perlindungan hukum kepada petani yang menggarap tanah Negara yang dikuasai oleh pihak Perhutani sebagai kepanjangan tangan Negara. Terlebih lagi tanah-tanah tersebut tidak digarap oleh Perhutani bahkan

4 Jatengheadline, "Perhutani Pati Tutup Mata Petani Menderita", www.Jatengheadline.com, diakses 12 Maret 2016.

5 Andri Parangin-angin, "Konflik Petani Dengan Perhutani (Studi Kasus Di Desa Genteng Kecamatan Sukasari Kabupaten Sumedang)", http://stnprmsumedang.co.id, diakses 15 Maret 2016. 
terkesan ditelantarkan. Oleh karena itu, isu hukum ini sangat menarik untuk diteliti dari sisi perlindungan hukum kepada Petani yang menggarap tanah Negara yang dikuasi oleh Perhutani khususnya yang ditelantarkan atau tidak digarap oleh Perhutani.

Berkaitan dengan latar belakang tersebut maka penulis akan membatasi kajian penulisan jurnal ini pada dua hal yakni untuk menganalisis mengapa petani tidak diperbolehkan menggarap tanah negara yang dikuasi oleh Perhutani yang mengakibatkan konflikdanbahkanditelantarkanolehPerhutani dan Bagaimana bentuk perlindungan hukum terhadap Petani yang menggarap tanah negara yang dikuasai oleh Perhutani agar tidak terjadi konflik horizontal lagi antara masyarakat dan Perhutani. Penulisan jurnal ini didasarkan pada hasil penelitian hukum normatif yang didukung dengan data empirik.

\section{Pembahasan}

\section{A. Konflik Horizontal antara Petani Penggarap Tanah dan Perum Perhutani}

Banyak teori tentang petani yang diungkapkan oleh para ahli. Menurut para ahli, terdapat beberapa definisi. Menurut Anwas, ${ }^{6}$ Petani adalah orang yang melakukan cocok tanam dari tanah pertaniannya atau memelihara ternak dengan tujuan untuk memperoleh kehidupan dari kegiatan itu. Petani menurut Slamet ${ }^{7}$ disebut petani 'asli' apabila memiliki tanah sendiri, bukan sekedar penggarap maupun penyewa. Berdasarkan hal tersebut, secara konsep, tanah merupakan bagian yang tidak dapat dipisahkan dari kehidupan seorang petani.

Poin penting dari konsep di atas bukan hanya terletak pada soal, bahwa tanah adalah alat produksi utama petani, melainkan bahwa alat produksi tersebut mutlak dimiliki seorang petani. Implikasinya, petani yang tidak memiliki tanah sendiri tidak dianggap sebagai petani sejati atau asli. Implikasi politisnya, petani mutlak dan mempertahankan dan menjaga hak kepemilikannya atas tanah. Dengan demikian, kita bisa mengatakan bahwa konsep petani asli memiliki kaitan sosial-budaya-politik. ${ }^{8}$

Salah satu modal utama dalam usaha pengembangan pertanian adalah tersedianya tanah yang cukup memadai dan jenis-jenis tanah yang cocok dengan karakteristik tanaman yang akan dikembangkan, serta tersedianya sumber daya manusia yang handal. Tjodronegoro dan Wiradi, mengatakan bahwa fungsi sosial dari tanah tidak hanya sebagai tempat tinggal untuk memenuhi kebutuhan papan dan sumber-sumber pendapatan sebagai sandaran hidup petani, tetapi juga terdapat fungsi-fungsi sosial yang memungkinkan

\footnotetext{
6 Organic HCS, "Sekilas Definisi dan Konsep, Petani dan Pertanian", https://organichcs.com/2014/01/10/ sekilas-definisi-konsep-petani-dan-pertanian/, diakses 9 Desember 2015.

7 Ibid.

8 Ibid.
} 
mereka melakukan interaksi dan berkembang. Namun, sejak awal tahun 2000-an, akibat pembangunan dan ekonomi uang yang memasuki pedesaan, timbul berbagai persoalan penting berkaitan dengan tanah itu. Oleh karena sebagian tanah pertanian mereka telah berubah fungsi menjadi berbagai fasilitas umum, seperti perkantoran, pasar, jalan raya dan pemukiman penduduk, dan mengalami perubahan, baik kepemilikan, luas maupun fungsinya, maka kehidupan sosialpun terpengaruh. Misalnya, masalah perubahan nilai-nilai kehidupan sosial keluarga dan nilai-nilai interaksi sosial. Dalam konteks perubahan demikian, Scott menunjukkan bahwa masalah-masalah itu berkaitan juga kepada nilai-nilai hubungan patron-klien dimana meningkatnya buruh tani yang tidak berpatron. Menurut Vago, fenomena sosial tersebut lahir dari sebuah akibat "pembangunan terencana". Sedangkan, hasil temuan Geertz, di Mojokerto, Jawa Timur dan Tabanan di Bali menyebutnya sebagai perubahan perilaku masyarakat yang cukup signifikan berkaitan dengan fungsi ekonominya, dimana struktur sosial yang ada merupakan bagian yang tidak terpisahkan dari luas tanah. Jadi, kemampuan produksi di sektor pertanian bagi masyarakat sangat berpengaruh pada pola dan nilai-nilai kehidupannya.

Dalam kehidupan masyarakat, pada umumnya disadari tidak ada gejala sosial yang sama sekali terisolir dari gejala lainnya.
Artinya, pembangunan dan perubahan merupakan dua variabel yang mempunyai hubungan berakibat dalam kehidupan manusia dimana antara kebutuhan akan pembangunan dengan kebutuhan tanah pertanian selalu terdapat banyak benturan kepentingan dengan aspek lainnya. Di lingkungan masyarakat, hal ini merupakan akibat proses transformasi struktur ekonomi dan mobilitas penduduk (dari perkotaan ke pedesaan) yang pada gilirannya menuntut adanya transformasi alokasi penggunaan sumber daya tanah pertanian.

Sedangkan hubungan petani dan hutan adalah, hutan rakyat adalah hutan yang dibangun dan dikelola oleh rakyat, kebanyakan berada di atas tanah milik atau tanah adat, yang ditanami pohon-pohonan yang terdiri dari berbagai jenis tanaman. Luas hutan rakyat di Indonesia kurang lebih mencapai 1.560 .229 ha atau $1,13 \%$ dari total kawasan hutan di Indonesia $(133,69$ juta ha). Hutan bagi masyarakat yang tinggal disekitarnya merupakan sumber ketahanan pangan, karena masyarakat bisa memanfaatkan hasil hutan dengan menanam berbagai jenis tanaman kehutanan, pertanian, dan perkebunan untuk memenuhi kebutuhan. ${ }^{9}$ Dalam hal ini diperlukan Peran Hutan Rakyat. Hutan rakyat sebagai alternatif untuk mengatasi masalah tanah kritis dan meningkatkan pendapatan masyarakat, dalam pengelolaannya masih dilakukan secara

9 Lembaga Penelitian Institut Pertanian Bogor, Sistem Pengelolaan Hutan Rakyat, (Bogor: Lembaga Penelitian Institut Pertanian Bogor, 1990), hlm. 70-72. 
sederhana dan belum memperhatikan prinsipprinsip ekonomi yang menguntungkan sehingga manfaat yang diperoleh belum optimal karena lebih mengandalkan faktor alam dengan teknik budidaya yang minim serta kurang memperhatikan kelestarian hasil. Hutan rakyat dianggap sebagai tabungan untuk kebutuhan yang mendesak dan merupakan usaha sampingan mereka. Sehubungan dengan hal diatas maka perlu dicari sistem pengelolaan hutan rakyat yang memberi manfaat yang optimal, yang mampu memberikan produksi kayu yang tinggi dan meningkatkan kesejahteraan petani dengan tetap memperhatikan daya dukung dan fungsi hutan tersebut.

Hutan merupakan salah satu sumber dan jenis konflik yang sering terjadi selama Orde Baru dan hingga sekarang belum semua kasus tuntas penyelesaiannya. Sebagai karunia Tuhan yang wajib disyukuri, hutan dikelola dengan prinsip-prinsip yang justru makin jauh dari spirit Ilahiyyah. Ideologi developmentalism yang dipilih sebagai paradigma pembangunan rezim yang berkuasa telah menjadikan hutan dan hasil-hasilnya sebagai komoditas semata, seraya meminimalisir peran serta masyarakat yang tinggal di sekitar hutan. Hutan tak lagi menjadi sumber berkah bagi semua karena negara dan warga saling berebut dan tak mau berbagi. Sebagai kekayaan yang dikuasai negara, hutan seharusnya diurus dan dimanfaatkan optimal, serta dijaga kelestariannya untuk sebesar-besar kemakmuran rakyat, baik generasi sekarang maupun generasi mendatang. Norma ideal ini tak mudah diwujudkan. Banyaknya pihak yang berkepentingan terhadap hutan dan hasil-hasilnya, menjadi faktor utama mengapa konflik ini tidak mudah diselesaikan.

Praktek pengelolaan dan pemanfaatan sumber daya hutan di Jawa cenderung diwarnai oleh fenomena konflik, yakni konflik antara penduduk desa-desa di sekitar hutan (populer dengan sebutan masyarakat desa hutan/ selanjutnya disebut MDH) dengan Perum Perhutani. Perbedaan persepsi mengenai hutan dan berbagai kepentingan dalam pemanfaatan hutan dituding sebagai biang konflik. Konflik tersebut dapat diredam oleh kekuatan represif Orde Baru. Selanjutnya berkembang pada masa reformasi 1998, yang ditandai dengan aksi penjarahan hutan oleh masyarakat di sekeliling hutan dalam bentuk pengambilan kayu yang identik dengan balas dendam terhadap perlakuan Perhutani selama ini.

Secara historis, kebijakan pemerintah dalam eksploitasi hutan dalam rangka memperoleh devisa negara cenderung mengekor pada kebijakan pemerintah kolonial Hindia-Belanda. Negara terlalu mengeksploitasi hutan seraya hak-hak $\mathrm{MDH}$ diabaikan. Kepentingan petani lokal dan penduduk yang berdomisili di tepian hutan dengan kepentingan perusahaan pemegang hak pengelolaan hutan tidak dapat dikompromikan. Petani memandang bahwa secara tradisional hutan dan tanah yang ada di kawasan itu merupakan sumber 
penghidupan, cadangan perluasan tanah perladangan dan sekaligus sebagai daerahfood security. Sementara perusahaan pemegang hak penguasaan hutan memandang bahwa kawasan hutan merupakan tanah yang secara legal telah dikuasakan oleh negara kepadanya untuk dikelola secara komersial dengan tujuan making as much profit as possible.

Kedua belah pihak dengan kepentingannya masing-masing itu menjadikan pihak lain sebagai ancaman yang harus dienyahkan. Bagi penduduk lokal, gangguan ekologi yang datang dari luar hutan akan mengancam kehidupan sosial dan ekonomi mereka. Sebaliknya bagi pengelola hutan, gangguan dalam proses produksi yang datang dari sikap tradisionalisme akan mendatangkan kerugian atas investasinya. Persoalan sosial ini masih berlangsung hingga saat ini dan tidak jarang menimbulkan konflik yang dapat mengancam harmonisasi sosial. Otoritas penguasaan dan pengelolaan sumber daya hutan di Jawa diberikan kepada Perum Perhutani berdasarkan UU Kehutanan juncto PP No. 15 tahun 1972, PP No. 2 Tahun 1978 dan PP No. 36 tahun 1986 tentang Pendirian Perum Perhutani. Perum Perhutani merupakan Badan Usaha Milik Negara (BUMN) yang bernaung di bawah Departemen Kehutanan. Tegasnya, hak yang dimiliki oleh Perum Perhutani atas sumber daya hutan adalah hak pengelolaan yang merupakan gempilan dari hak menguasai negara (HMN).

Perum Perhutani pada dasarnya memainkan tiga peran pokok, yaitu sebagai penguasa tanah hutan (government land oral), perusahaan kehutanan (forest enterprise) dan institusi konservasi hutan (forest conservation institution). Sedangkan komponen sumber daya hutan yang dikuasai oleh Perum Perhutani, antara lain adalah tanah hutan dan hasil hutan (baik kayu maupun non-kayu). Tanah yang dikuasai Perhutani sangat luas dengan komoditas yang bernilai ekonomi sangat tinggi. Untuk melindungi keamanan komoditas tersebut, diterbitkanlah PP No. 28 Tahun 1985 tentang Perlindungan Hutan. Pasal 9 menegaskan bahwa:

"Selain dari petugas-petugas
kehutanan atau orang-orang
yang karena tugasnya atau
kepentingannya dibenarkan berada
di dalam kawasan hutan, siapapun
dilarang membawa alat-alat yang
lazim digunakan untuk memotong,
menebang, dan membelah pohon di
dalam kawasan hutan; Setiap orang
dilarang melakukan penebangan
pohon-pohon dalam hutan tanpa
izin dari pejabat yang berwenang;
Setiap orang dilarang mengambil/
memungut hasil hutan lainnya tanpa
izin dari pejabat yan berwenang."

Pengaturan hukum untuk perlindungan hutan yang demikian itu dimana Perum Perhutani berada di garis depan merupakan ekspresi dari model hukum represif (represive law) yang dicirikan dengan pendekatan keamanan (security approach), menekankan sanksi-sanksi, dan mengedepankan penampilan petugas-petugas polisi khusus kehutanan, untuk membatasiatau bahkan menggusurakses sumber daya hutan oleh masyarakat setempat. 
Konsekuensi yuridisnya, setiap penduduk desa yang mengakses, memanfaatkan dan menggunakan sumber daya hutan untuk kebutuhan hidup (subsistensi), dikualifikasi atau distigmatisasi sebagai pelanggar hukum, perambah hutan, penjarah hasil hutan, peladang liar, pencuri kayu, perusuh keamanan hutan, dan lain-lain.

Kasus konflik tanah kawasan hutan dengan Masyarakat yang tinggal di sekitar kawasan hutan dan sudah bertahun-tahun menggarap tanah tersebut mulai menuntut hak atas tanahnya. Sementara pihak pengelola hutan beralasan, tanah kawasan hutan tidak bisa digarap oleh petani (termasuk tidak bisa seenaknya memanfaatkan hasil-hasil hutan) sebab kawasan itu masuk dalam register kehutanan. Dalam kasus ini, BPN tidak memproses (tuntutan petani) kecuali ada pelepasan kawasan hutan dari menteri kehutananan.

Sejak tiga dekade terakhir, praktek pengelolaan dan pemanfaatan sumber daya hutan cenderung diwarnai oleh fenomena konflik, yakni konflik antara penduduk desa-desa di sekitar hutan dengan Perum Perhutani suatu perusahaan milik negara. Perbedaan persepsi mengenai hutan dan kepentingan-kepentingan dalam pemanfaatan hutan dituding sebagai sumber konflik di berbagai kawasan hutan. Dengan kata lain, persoalan penguasaan hutan oleh negara merupakan salah satu dari basis konflik sosial di masyarakat sekitar hutan. Manakala negara menguasai hutan, biasanya seluruh kebijakan- kebijakan diarahkan untuk melindungi haknya dan menempatkan orang lain di pihak seberang. Dalam konteks civil society, terjadi tarik-menarik antara negara (Perum Perhutani) dan warga untuk menguasai sumber daya hutan akan berlangsung secara konstan untuk memperebutkan alokasi, kontrol, dan akses terhadap sumber daya yang ada. Berdasarkan kajian di lapangan, konflik tanah dapat dibedakan menjadi dua macam akar masalah konflik.

Pertama, konflik yang berlatar ketiadaan akses masyarakat sekitar hutan untuk bisa mengelola hutan. Dalam hal ini, seluruh kawasan hutan dikuasai oleh Perum Perhutani (perusahaan kehutanan negara) meskipun wilayah hutan tersebut masuk wilayah desa. Akibatnya, masyarakat di sekitar hutan tak memiliki kesempatan untuk menggarap tanah-tanah hutan tersebut. Sebagian besar masyarakat pinggir hutan (yang sebagian besar adalah petani penggarap dan buruh tani) hidup dalam kemiskinan dan terpinggirkan. Gelondongan kayu jati yang gagah berdiri, bernilai jutaan rupiah per kubiknya hanya sebagai pemandangan getir penduduk setempat. Meskipun rumah dan lingkungan hidup mereka dikelilingi oleh sumber daya alam (kayu) yang sangat mahal, namun semua itu milik orang lain (perusahaan, negara).

Kedua, adalah konflik hutan yang berbasiskan (hak atas) tanah. Konflik ini berlatar belakang pengambilalihan tanahtanah hasil membuka hutan atau tanah-tanah garapan masyarakat oleh Perum Perhutani. 
Klaim penguasaan tanah hutan memiliki dampak sangat serius bagi petani sekitar hutan karena mereka harus berhadapan dengan Perum Perhutani yang memiliki kekuatan penuh untuk memeriksa, menggeledah, menyita, menangkap dan menahan seseorang yang diduga melakukan tindak pidana yang menyangkut hutan.

Cara-cara menyelesaikan sengketa tanah dengan hukum negara biasanya dilakukan oleh pihak-pihak yang merasa memiliki bukti-bukti hukum yang kuat. Hal itu ditunjukkan pada kasus sengketa tanah yang melibatkan warga dengan Perhutani. Penyelesaian sengketa tanah kawasan hutan pada masa Orde Baru menggunakan cara-cara demikian. Pemerintah yang otoriter akan menggunakan hukum represif untuk menyelesaikan masalahnya. Norma hukum dalam menyelesaikan sengketa tanah bersifat formal dan positif. Formal artinya bersifat tertulis dan mengikat semua individu yang menjadi subyek hukum, tak peduli apakah ia sudah membaca, mempelajari dan mengetahuinya atau tidak. Semua orang yang telah memenuhi syarat seperti ditentukan oleh hukum diandaikan sebagai subyek yang terikat hukum. Inilah yang disebut asas "fictie hukum" yang artinya setiap orang dianggap telah mengetahui adanya suatu undang-undang yang telah diundangkan. Positif artinya bersifat baku prosedurnya dan berkepastian hukum. Semua orang yang akan menggapai keadilan hukum disediakan aturan bagaimana beracara di pengadilan dengan ancaman sanksi yang jelas.
Untuk menyelesaikan konflik yang telah terjadi, bukan hanya pendekatan keamanan dan hukum yang dipilih oleh Perhutani. Banyak peluang penggunaan cara-cara yang lebih manusiawi yang juga dapat diimplementasikan dalam menyelesaikan konflik tanah kawasan hutan. Faktanya masih ada kesenjangan antara konsep kebijakan dan implementasi di lapangan. Perhutani menawarkan mekanisme penyelesaian berupa program Pengelolaan Hutan Bersama Masyarakat (PHBM/ selanjutnya disebut Managing Forest with Community), yang pada era Orde Baru disebut kerja sama model tumpangsari. PHBM merupakan sistem pengelolaan sumber daya hutan yang dilakukan oleh perusahaan (Perum Perhutani) dan masyarakat kawasan hutan dengan semangat berbagi agar manfaat sumber daya hutan dapat terwujud secara optimal. Semangat yang dibangun oleh Perum Perhutani dengan PHBM ini adalah kemauan (willingness) masyarakat sekitar hutan dan pihak-pihak lain yang tertarik untuk berbagi dalam pengelolaan sumber daya hutan berdasarkan prinsip-prinsip keseimbangankeberlanjutan, kesesuaian dan keselarasan dalam pengelolaan hutan.

Perum Perhutani merumuskan prinsipprinsip dasar PHBM adalah sebagai berikut: a) jujur dan demokratis (fairness and democracy); b) keterbukaan dan kebersamaan (openness and togetherness); c) mau belajar dan saling memahami (lesson learned and understanding on each other); d) kejelasan antara hak dan kewajiban (clarity of right 
and duty); e) pemberdayaan ekonomi demokrasi (empowerment of democracy economic); f) kerjasama lembaga (institution cooperativeness); g) perencanaan partisipatif (participation planning); h) sederhana dalam sistem dan prosedur (simplicity in system and procedure); i) perusahaan sebagai fasilitator; j) kesesuaian antara pengelolaan dan karakteristik area.

PHBM sebenarnya adalah pelaksanaan dari amanat Pasal 30 UU No. 41 Tahun 1999 tentang Kehutanan yang berbunyi:

"dalam rangka pemberdayaan ekonomi masyarakat,setiap badan usaha milik negara, badan usaha milik daerah dan badan usaha milik swasta Indonesia yang memperoleh izin usaha pemanfaatan jasa lingkungan, pemanfaatan hasil industri hutan kayu diwajibkan bekerja sama dengan koperasi masyarakat setempat "

Dengan demikian, partisipasi masyarakat dalam pengelolaan hutan menjadi sangat penting. Program demikian sesungguhnya bukan hal baru, karena sudah sejak lama Perhutani mencoba bergandengan tangan dengan warga yang tinggal di sekitar hutan. Di samping itu, setelah masyarakat mengajak bicara dengan Perhutani, dan menghasilkan kesepakatan pengelolaan kawasan hutan yang disebut Management Regime Mozaik (MR Mozaik). MR Mozaik merupakan kesepakatan membagi tanah antara Perhutani dan masyarakat. Misalnya, tanah satu hektar dibagi menjadi dua: separuh ditanami pohon jati dan separuh lainnya dijadikan tanah pertanian oleh masyarakat. Pada waktu itu, ditetapkan tanah percontohan MR Mozaik seluas 62 hektar. Untuk itu para petani diwajibkan menanam, memelihara dan menjaga pohon-pohon jati milik perhutani.

\section{B. Bentuk Alternatif Perlindungan Hukum terhadap Petani Penggarap}

Masyarakat Indonesia adalah masyarakat yang majemuk, dalam kemajemukan timbul berbagai hal, maka fenomena konflik atau sengketa merupakan suatu keniscayaan. Konflik-konflik atau sengketa dalam perebutan sumber daya alam, ekonomi, sosial maupun politik dapat selalu terjadi setiap saat, dan bisa berujung menjadi suatu sengketa. Dalam hubungan ini, Paul Bohannan ${ }^{10}$ menyatakan: "conflict is useful. In fact society is impossible without conflict. But society is worse than impossible without control of conflict....". Suatu konflik atau sengketa yang tidak segera diselesaikan dapat mengakibatkan suatu persoalan keadilan.

Setiap masyarakat mempunyai mekanisme tersendiri untuk menyelesaikan suatu konflik atau sengketa, apakah melalui mekanisme yang disediakan oleh hukum negara state institution, atau melalui mekanisme yang sudah dikenal oleh masyarakat folk institution. Pilihan untuk menyelesaikan konflik atau

10 Paul Bohannan, Dalam pengantar Buku Law \& Warfare; Studies in The Antropology of Conflict, (Austin and London: University of Texas Press, 1980), p. xii. 
sengketa mereka adalah dapat melalui jalur formal peradilan (litigasi) atau jalur alternatif lain diluar pengadilan. Masyarakat perkotaan lebih memilih sistem hukum formal, namun pada umumnya pilihan ini dipandang korup, mahal, lamban dan berjarak. ${ }^{11}$ Fakta bahwa pada jalur formal peradilan terjadi penumpukan perkara di Mahkamah Agung, awal tahun 2005 meningkat menjadi 21.000 perkara. Pada tahun 2009 Mahkamah Agung berhasil menurunkan tunggakan perkara, pada akhir Desember 2007 tunggakan mencapai 6.794 perkara, sedangkan akhir Desember hanya mencapai 5.657 perkara.

Berdasarkan data tersebut adanya keterbatasan atau kurangnya kemampuan negara melayani masyarakatnya memperoleh keadilan dalam pelayanan hukum, maka beberapa persoalan yang akan muncul, mulai dari eigenrechting, sampai pada persoalan perubahan nilai-nilai dan penyimpangan terhadap nilai-nilai budaya dalam masyarakat bahkan legal gap yaitu, terdapat silang selisih antara apa yang dihukumkan secara resmi oleh kekuasaan nasional dan apa yang dijalani dalam kehidupan sehari-hari sebagai hukum oleh masyarakat setempat.

Dalam seminar yang diselenggarakan Tim Justice dan organisasi LAPPAN di Ambon, 17 Februari 2005 menyatakan:

"Pilihan masyarakat terhadap mekanisme penyelesaian sengketa informal bukan hanya disebabkan mekanisme ini murah, cepat danmudah. Tetapi aspek yang lebih penting adalah kepatuhan wargaterhadap suatu pendekatan yang memberikan rasa tertib dan tenteramdalam diri dan komunitasnya." 12

Manfaat dan pentingnya penyelesaian sengketa yang dapat dilakukan oleh masyarakat itu sendiri juga dikatakan oleh Adrianus Meliala yaitu: ${ }^{13}$

Dalam kaitan itu diperlukan mekanisme penyelesaian sengketa alternatif atau alternative dispute resolution yang tidak membuat masyarakat tergantung pada dunia hukum yang terbatas kapasitasnya, namun tetap dapat menghadirkan rasa keadilan dan penyelesaian masalah. Mekanisme tersebut sebenarnya telah memiliki dasar hukum dan telah memiliki preseden serta pernah dipraktikkan di Indonesia walau jarang disadari. Mekanisme tersebut juga memiliki potensi untuksemakin dikembangkan di Indonesia.

Istilah Alternative Dispute Resolution (ADR) merupakan istilah asing, sehingga juga memiliki istilah dalam Bahasa Indonesia, antara lain seperti Pilihan Penyelesaian Sengketa (PPS), Mekanisme Alternatif Penyelesaian Sengketa (MAPS), dan Pilihan Penyelesaian Sengketa (PPS) di luar pengadilan. Alternative Dispute Resolution (ADR) merupakan suatu "penyelesaian

11 Ibid., p. 13-14.

12 Vja Ambon, 2005, "Mekanisme Penyelesaian Sengketa Informal di Kabupaten Buru, Kota Ambon dan Kabupaten Maluku Tengah", e-journal.stie-aub.ac.id, diakses 18 Desember 2015.

13 Adrianus Meliala, "Penyelesaian Sengketa Alternatif; Posisi dan Potensinya di Indonesia", www. adrianusmeliala.co.id, diakses 10 Desember2015. 
sengketa di luar pengadilan yang dilakukan secara damai",.Pengertian mengenai ADR ini juga diaturdalam Undang-Undang Nomor 30 Tahun 1999 tentang Arbitrase dan Alternatif Penyelesaian Sengketa, dimana dalam Undang-Undang Nomor 30 Tahun 1999 ini yang dimaksud dengan ADR merupakan:

Suatu pranata penyelesaian sengketa di luar pengadilan berdasarkan kesepakatan para pihak dengan mengesampingkan penyelesaian sengketa secara litigasi di pengadilan.

ADR adalah sebuah konsep yang mencakup berbagai bentuk penyelesaian sengketa selain dari pada proses peradilan melalui caracara yang sah menurut hukum, baik berdasarkan pendekatan konsensus, seperti negosiasi, mediasi dan konsiliasi atau tidak berdasarkan pendekatan konsensus, seperti arbitrase.

Dalam Black's Law dictionary dikatakan: Alternative Dispute Resolution is a procedure for steling a dispute by means other than litigation, such a arbitration or mediation;

ADR can be defined as encompassing all legally permitted processes of dispute resolution other than litigation, while this definition (or something like it) is widely used, ADR proponents may object to it on the ground that it privileges litigation by piving by impression that litigation is the normal or standard process of dispute resolution, while alternative processes are aberrant or deviant. That impression is false. Litigation is relatively rarely used process of dispute resolution. Alternative processes, especially negotiation are used fare more frequently. Even disputes involving lawyers are resolved by negotiation far more often than litigation. So ADR is not defined as everything-but-litigation because litigation is the norm. Litigation is not the norm. ADR is defined as everything-but-litigation because litigation, as a matter of law, is the default process of dispute resolution" Stephen J Ware ${ }^{14}$.

George Applebey, dalam tulisannya yang berjudul "An Overview of Alternative Dispute Resolution"juga berpendapat bahwaADR pertama-tama adalah merupakan suatu eksperimen untuk mencari model-model:

a. Model-model baru dalam penyelesaian sengketa;

b. Penerapan-penerapan baru terhadap metode-metode lama;

c. Forum-forum baru bagi penyelesian sengketa;

d. Penekanan yang berbeda dalam pendidikan hukum.

Menurut Gunawan Wijaya ${ }^{15}$, Penyelesaian Sengketa Alternatif pada dasarnya merupakan 
suatu bentuk penyelesaian sengketa di luar pengadilan, yang didasarkan pada kesepakatan para pihak yang bersengketa. Dalam literatur hukum, penggunaan mekanisme penyelesaian sengketa win-win solution biasanya disebut Penyelesaian Sengketa Non-Litigasi atau disebut ADR (Alternative Dispute Resolution) atau Alternatif Penyelesaian Sengketa.

M. zaidun ${ }^{16}$, menerjemahkan ADR (Alternative Dispute Resolution) menjadi Mekanisme Alternatif penyelesaian Sengketa (MAPS), yang tumbuh pertama kali di di Amerika Serikat adalah merupakan jawaban atas ketidakpuasan (dissatisfaction) yang berkembang pada sistim (praktek) peradilan mereka yang bermuara pada persoalan waktu, biaya dan kemampuannya dalam menangani kasus-kasus komplek.

Penggunaan mekanisme penyelesaian sengketa alternatif berupa negosiasi, arbitrase, litigasi atau mediasi sudah lasim digunakan diberbagai negara di dunia, sejak tahun 1980an. Di Amerika Utara maupun di Australia lazim ditemukan Court Annexedmediation atau Court Annexed Arbitration, karena model penyelesaian melalui negotiation dan mediation khususnya merupakan mekanisme alternatif penyelesaian sengketa secara koperatif yang dapat diintegrasikan dengan sistem peradilan yang $\mathrm{ada}^{17}$.
Upaya-upaya menyelesaikan sengketa secara kooperatif diluar peradilan (untuk sementara waktu) merupakan policy/ kebijakan pengadilan agar dapat menghasilkan suatu keputusan bersama yang memberi kemungkinan perasaan "keadilan bersama" yang pada akhirnya akan dituangkan dalam keputusan hakim (pengadilan) ${ }^{18}$.

Prinsip "kooperatif" ini dalam akar budaya Indonesia dapat dikatakan mempunyai semangat yang sama dengan prinsip "musyawarah". Oleh karena itu semangat untuk menyelesaikan berbagai persoalan kemasyarakatan termasuk persoalan hukum melalui upaya musyawarah untuk mencapai mufakat jelas merupakan nilai-nilai filosofis dan kultural yang benarbenar dapat merupakan landasan bagi pengembangan Mekanisme penyelesaian Sengketa di Indonesia. Model-model penyelesaian sengketa melalui negosiasi, mediasi, dan konsiliasi merupakan model penyelesaian sengketa yang mengandung dan mengutamakan prinsip-prinsip musyawarah untuk mencapai mufakat yang selaras dengan budaya Indonesia ${ }^{19}$.

Wiliam Ury, ${ }^{20}$ menyatakan ada tiga faktor utamayangmempengaruhiprosespenyelesaian sengketa yaitu kepentingan (interest), hak-hak

16 M. Zaidun, Mekanisme Alternatif Penyelesaian Sengketa (MAPS), dalam Bahan Ajar Penyelesaian Sengketa Alternatif (PSA) Universitas Airlangga 1945- 2004, (Surabaya: Fakultas Hukum Universitas Airlangga, 2004), hlm. 1.

17 Ibid.

18 Ibid., hlm. 3.

19 Ibid.

20 M. Zaidun, Mekanisme Alternatif Penyelesaian Sengketa (MAPS), dalam Bahan Ajar Penyelesaian Sengketa Alternatif (PSA) Universitas Airlangga 1945-2004, (Surabaya: Fakultas Hukum Universitas Airlangga 2004), hlm. 5. 
(rights), dan status kekuasaan (power). Para pihak yang bersengketa ingin kepentingannya tercapai hak-haknya terpenuhi dan ingin status kekuasaannya diperlihatkan, dimanfaatkan dan dipertahankan.

Tujuan mekanisme penyelesaian sengketa menurut Goldberg dan rekan ${ }^{21}$ adalah :

a. Mengurangi kemacetan pengadilan;

b. Meningkatkan keterlibatan masyarakat dan proses penyelesaian sengketa;

c. Memperlancar jalur pengadilan;

d. Memberikan kesempatan bagi tercapainya penyelesaian sengketa yang menghasilkan keputusan yang dapat diterima oleh semua pihak.

Penyelesaian sengketa secara informal pada dasarnya merupakan suatu bentuk penyelesaian sengketa diluar pengadilan, yang didasarkan pada kesepakatan para pihak yang bersengketa $^{22}$. Secara umum Penyelesaian sengketa alternatif dapat digolongkan ke dalam:

1. Berdasarkan sifat keterlibatan pihak ketiga yang menangani penyelesaian sengketa alternatif tersebut, yaitu : Mediasi, Konsiliasi, dan Arbitrase.

2. Berdasarkan pada sifat putusan yang diberikan dalam proses penyelesaian sengketa alternatif tersebut : Mediasi, konsiliasi, Arbitrase.

3. Berdasarkan sifat kelembagaannya: Lembaga ad hoc, dan Institusi
Penyelesaian sengketa Alternatif (Institusi permanen).

4. Berdasarkan ada tidaknya unsur asing atau luar negeri, karena dikenal ada Penyelesaian sengketa Nasional dan penyelesaian sengketa Internasional (asing). Dikatakan Internasional karena proses penyelesaian sengketa mengandung unsur luar negeri (asing).

Otoritas pada posisi setiap aktor konflik, akan menempatkan masing-masing aktor pada posisi superordinasi dan subordinasi. Ritzer dan Goodman membantu menerangkan otoritas yang dimaksud Dahrendorf, bahwa "setiap otoritas dalam asosiasi (masyarakat) bersifat dikotomis; dua, dan hanya dua kelompok konflik dapat terjadi dalam asosiasi mana pun. Mereka yang memegang otoritas dan mereka yang berada pada posisi subordinat memiliki kepentingan yang 'substansi dan arahnya berlawanan'. Akhirnya, ketika posisi yang berada pada posisi subordinat akan selalu berupaya melakukan tindakan yang melawan posisi superordinat. Begitu sebaliknya, posisi superordinat akan tetap mempertahankan status quo sebuah konflik. ${ }^{23}$

Dahrendorf mengklasifikasikan ada tiga kelompok yang merupakan cikal bakal aktor konflik. Pertama, Kelompok Semu (quasi group) sebagaimana dikutip Ritzer dan Goodman ${ }^{24}$ yaitu himpunan pemangku posisi dengan kepentingan-kepentingan peran

21 Ibid.

22 Gunawan Wijaya, op.cit.

23 George Ritzer, Teori Sosiologi dari Sosiologi Klasik sampai Perkembangan Terakhir Postmodern, (Yogyakarta: Pustaka Pelajar, 2012), hlm. 454.

24 George Ritzer, Ibid., hlm. 454. 
yang identik. Mengutip Malinowski, ciri-ciri kelompok semu menurut Dahrendorf, sebagai berikut: ${ }^{25}$

1. Sebuh inti, sistem nilai yang bertujuan mengejar tujuan bersama organisasi.

2. Personal; orang-orang yang bertugas mengaturnya.

3. Norma tertentu.

4. Peralatan material.

5. Kegiatan tertentu yang teratur.

6. Sebuah objektif.

Kedua, Kelompok Kepentingan. Dahrendorf menggambarkan kedua kelompok sebagai berikut: ${ }^{26}$

Mode perilaku bersama menjadi ciri dari kelompok kepentingan yang direkrut dari kelompok semu yang lebih besar. Kelompok kepentingan adalah kelompok menurut pengertian sosiologi; dan mereka adalah agen sesungguhnya dari konflik kelompok. Mereka memiliki struktur, bentuk organisasi, bentuk organisasi, program atau tujuan, dan personel anggota.

Selanjutnya, Dahrendorf mendalilkan kemunculan kelompok-kelompok kepentingan yang berasal dari kelompok semu, bahwa kelompok semu dan kelompok kepentingan berdasarkan atas posisi peranan di dalam perserikatan yang dikoordinasi secara memaksa. Jadi 'situasi-kelas-nya' memaksa individu untuk menyesuaikan perilakunya dengan posisi yang ia harapkan dalam sebuah perserikatan. ${ }^{27}$ Sedangkan, aktor yang terlibat dalam konflik disebut dengan Kelompok Konflik atau kelompok yang benar-benar terlibat dalam konflik kelompok, muncul dari sekian banyak kelompok kepentingan tersebut. $^{28}$

Dahrendorf menyebutkan ada kondisi yang mendukung kemunculan sebuah kelompok konflik, yang merupakan pendorong terjadinya konflik:29

1. Kondisi teknis organisasi, yang bergantung dengan pembentukan kepemimpinan pada kader dalam kelompok semu dan kodifikasi sistem gagasan atau piagam perjuangan. Dalam konteks ini, jelas sangat diperlukan kemampuan bagaimana membangun sistem kepemimpinan (leadership) dan bagaimana menciptakan ideologi yang bisa mempersatukan para anggota. Bisa dinyatakan dengan kalimat lain, tidak akan ada kelompok kepentingan jika tidak muncul orang yang diakui anggota sebagai layak menjadi pemimpin. Kemudian pemimpin itu meyakinkan pertanyaan-pertanyaan anggota, mengapa harus melakukan perjuangan, dan bagaimana sistematika perjuangan yang harus dipilih.

25 Rachmad K. Dwi Susilo, op.cit., hlm. 325.

26 George Ritzer, op.cit., hlm. 284.

27 Ralf Dahrendorf, Konflik dan Konflik dalam Masyarakat Industri Sebuah Analisa-Kritik diterjemahkan oleh Ali Mandan dari karya asli Class and Class Conflict in Industrial Society, (Jakarta: Rajawali, 1968), hlm. 234.

28 George Ritzer, Douglas J. Goodman, op.cit., hlm. 284.

29 Rachmad K. Dwi Susilo, op.cit., hlm. 326-327. 
2. Kondisi politis, yang bergantung pada kelompok dominan untuk mengizinkan berdiri dan besarnya organisasi yang memiliki kepentingan berlawanan. Dengan kata lain, ini sangat berhubungan dengan kapasitas kelas pengatur (the ruling class) dalam mengorganisasikannya. Tanpa ada izin dari kelompok tersebut, tidak mungkin kelompok yang berbeda kepentingan bisa bergerak secara leluasa. Dalam konteks ini, kelompok kepentingan akan diuntungkan jika sistem negara tersebut semakin demokratis. Sebaliknya, kalau sistem politik dalam suatu negara bersifat totaliter, kelompok kepentingan semakin kecil kemungkinannya untuk muncul.

3. Kondisi sosial, yang berkaitan dengan kesempatan-kesempatan anggota kelompok semu untuk berkomunikasi dan kesempatan untuk merekrut anggotaanggota. Jika leadership, ideologi, dan suasana berorganisasi telah kondusif, maka yang diperlukan adalah kesempatan untuk berkomunikasi. Pemimpin perlu mengomunikasikan janji-janji perjuangan yang dikonkritkan dalam ideologi. Ia juga diperlukan untuk menyiasati perubahanperubahan yang bisa dikatakan terjadi detik per detik. Ia juga diperlukan untuk mengorganisasi dan memobiliasi anggota, kapan harus bergerak dan kapan harus mundur menyusun kekuatan.

Selanjutnya, melihat kondisi yang sering memengaruhi terjadinya konflik, dirumuskan beberapa proposisi-proposisi turunan sebagai berikut: 30

1. Semakin sedikit kondisi teknikal, sosial, dan politik dari organisasi, semakin hebat konflik terjadi.

2. Semakin sedikit mobilitas antara kelompok yang memiliki otoritas dan tidak memiliki otoritas, semakin hebat konflik akan terjadi.

3. Semakin sedikit kondisi teknikal, sosial, dan politik dari organisasi, semakin hebat kekerasan akan terjadi.

4. Semakin kecil kemampuan kelompokkelompok konflik mengembangkan kesepakatan terkait dengan pengaturan, semakin besar kekerasan akan terjadi.

5. Semakin hebat konflik, semakin akan terjadi reorganisasi dan perubahan struktural.

6. Semakin banyak kekerasan ada di konflik, semakin besar tingkatan reorganisasi dan perubahan struktural.

Dasar penjelasan konflik sosial, juga terletak pada dua jenis kepentingan. Dahrendorf menyebutnya dengan kepentingan laten dan kepentingan manifest. Dahrendorf menyebut harapan-harapan tak sadar ini dengan kepentingan laten. Kepentingan manifest adalah kepentingan laten yang telah disadari. Dahrendorf melihat analisis hubungan antara kepentingan laten dengan kepentingan manifest sebagai tugas utama teori konflik. Namun, aktor tidak perlu 
menyadari kepentingan mereka agar bertindak menurut kepentingan-kepentingan tersebut. ${ }^{31}$

Kepentingan laten belum mampu menggerakkan para aktor untuk melakukan konflik. Kepentingan laten ${ }^{32}$, diartikan juga sebagai tingkah laku potensial yang telah ditentukan bagi seseorang, karena dia menduduki peran tertentu, dan ia bisa berubah menjadi kepentingan nyata. Kemudian ketika kelompok yang belum menyadari kepentingan berubah menjadi sadar akan kepentingannya atau berubah menjadi kepentingan manifest, maka terbentuklah kelompok semu (quasi group). Namun, Dahrendorf juga menyusun hipotesis tentang kepentingan manifest bahwa:

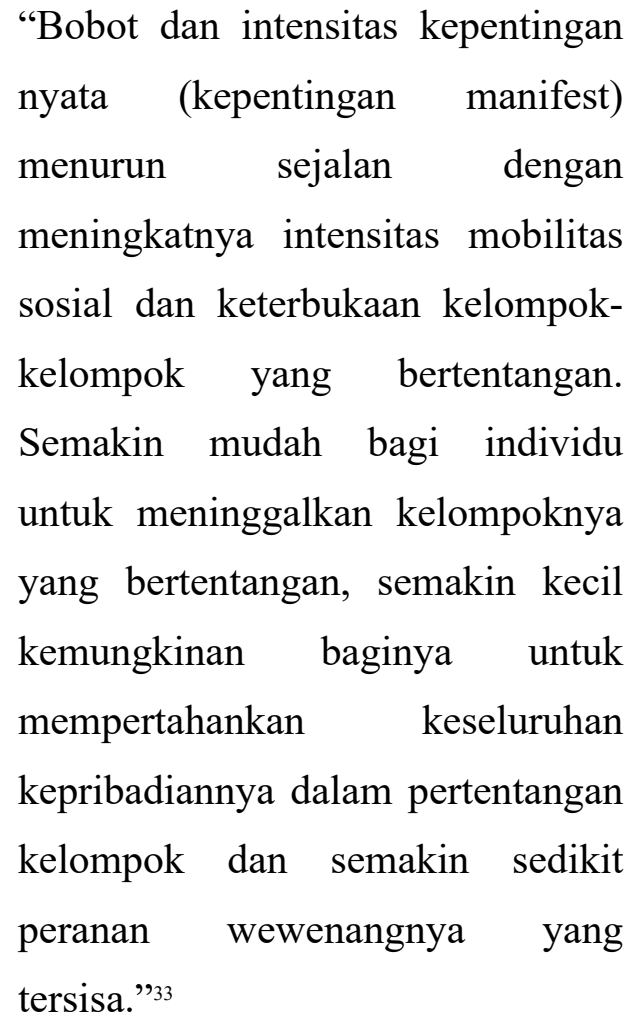
Konflik akibat pergeseran kepentingan laten menjadi kepentingan manifes ini biasanya tidak akan langsung terjadi berbenturan fisik atau saling mencemooh. Sengketa (dispute), dan konflik (conflict) adalah dua istilah yang sering dipakai untuk menggambarkan suatu situasi atau kondisi dimana orang-orang sedang mengalami perselisihan yang bersifat faktual maupun perselisihan-perselisihan yang ada pada persepsi mereka saja ${ }^{34}$. Sebagian sarjana berpendapat bahwa secara konseptual tidak terdapat perbedaan antara konflik dan sengketa, akan tetapi sebagian sarjana berpendapat bahwa istilah konflik (conflict) dapat dibedakan dari istilah sengketa (dispute):

Pertama, istilah konflik mengandung pengertian yang lebih luas dari pada sengketa karena konflik dapat mencakup perselisihan-perselisihan yang bersifat laten (latent) dan perselisihan-perselisihan yang telah mengemuka (manifest). Konflik atau perselisihan yang telah mengemuka disebut sengketa. Kedua, konflik merujuk pada perselisihanperselisihan yang para pihaknya sudah maupun belum teridetifikasi atau dapat diidentifikasi secara jelas. Ketiga, istilah konflik lebih sering ditemukan dalam kepustakaan ilmu-

31 George Ritzer, Douglas J. Goodman, op.cit., hlm. 284.

32 Rachmad K. Dwi Susilo, op.cit., hlm. 325.

33 Ralf Dahrendorf, op.cit., hlm. 235.

34 Takdir Rahmadi, Mediasi; Penyelesaian Sengketa Melalui Pendekatan Mufakat, (Jakarta: RadjaGrafindo Persada, 2010), hlm. 1. 
ilmu sosial dan politik dari pada

dalam kepustakaan ilmu hukum..."

Dalam masyarakat adat suatu konflik atau sengketa dapat terjadi karena adanya pelanggaran adat yaitu : “...terganggunya perimbangan (evenwicht, harmonie) antara dunia lahir dan dunia gaib, antara golongan manusia seluruhnya dan orang seorang, antara persekutuan dan teman semasyarakat ${ }^{35}$. Jadi segala perbuatan yang dianggap mengganggu keseimbangan dalam masyarakat adat tersebut merupakan pelanggaran adat (konflik, sengketa), misalnya kasus tersinggungnya wanita dayak Kalimantan Tengah atas pernyataan guru besar sosiolog Universitas Indonesia Thamrin Amal Tamagola pada sidang kasus video porno Ilham Nazriel”, Dalam adat dayak perilaku tidak senonoh itu sendiri tidak dibenarkan dan akan dikenakan jipen(denda adat). Permasatanah ini telah diselesaikan dengan melakukan sidang adat dilanjutkan dengan permintaan maaf ${ }^{36}$.

Latar belakang pemikiran masyarakat adat tentang apakah yang dapat disebut konflik atau sengketa (pelanggaran adat) adalah didasarkan pada :

Alam pikiran tradisional Indonesia (alam pikiran tradisional timur pada umumnya) bersifat kosmis,meliputi segala-galanya sebagai kesatuan (totaliter). Umat manusia menurut aliran pikiran kosmis itu adalah sebagian dari alam, tidak ada pemisahan-pemisahan dari berbagai macam lapangan hidup, tidak ada pembatasan antara dunia lahir dan dunia gaib, dan tidak ada pemisahan antara manusia dan mahluk mahluk lain. Segala sesuatu bercampur baur, dan bersangkut paut, segala sesuatu pengaruh mempengaruhi mempengaruhi. Dunia manusia adalah pertalian dengan segala hidup di dalam alam..." ${ }^{37}$

Alam pikiran tradisional Indonesia (alam pikiran tradisional timur pada umumnya) yang bersifat kosmis dan meliputi segalagalanya sebagai kesatuan (totaliter) juga digambarkan oleh Ter Haar sebagai “... suatu masyarakat yang terdiri dari gerombolan yang bertalian satu sama lain; terhadap alam yang tak kelihatan mata, terhadap dunia luar dan terhadap alam kebendaan,...."

Sengketa atau konflik terkadang diasosiasikan oleh masyarakat dengan fenomena kekerasan dan merupakan suatu keburukan oleh sebab itu konflik harus dicegah atau dihapuskan. Pemikiran ini memunculkan konsep conflict preventionatau conflict avoidance. Tindakan kekerasan seperti perkelahian, perusakan, pembakaran harta benda dan pembunuhan sampai kepada

35 Soepomo, Bab-bab Tentang Hukum Adat, (Jakarta: Balai Pustaka, 1996), hlm. 111.

36 Kompas online, “Tamrin dan Istri Minta Maaf”, www.kompas.com/, Diakses, 22 Januari 2011.

37 Soepomo, loc.cit.

38 Ter Haar, Asa-asas dan Susunan Hukum Adat (Beginselen En Stelsel Van Het Adatrecht), terjemahan Soebakti Poesponoto, (Jakarta: Pradnya Paramita, 1985), hlm. 27. 
peperangan merupakan sebuah fenomena yang buruk dalam masyarakat sehingga melahirkan konsep conflict prevention, dimana konflik harus dicegah melalui berbagai kebijakan masyarakat atau pemerintah. Konsep ini makin menguat di Indonesia apabila dilihat kenyataan bahwa konflik-konflik yang terjadi sering disertai dengan tindakan-tindakan kekerasan.

Pandangan lain yang mempersepsikan bahwa konflik bukan sesuatu yang buruk karena konflik harus dibedakan dengan tindakan kekerasan. “...konflik merupakan fenomena sosial yang bersifat semesta (universal) dan melekat (inherent) dalam kehidupan masyarakat, dalam pergaulan sosial antar individu maupun antar individu dengan kelompok..." ${ }_{39}$. Pencegahan dilakukan terhadap tindakan-tidakan kekerasan yang biasanya menyertai suatu konflik. Menghindari konflik dalam dinamika sosial masyarakat adalah tidak mungkin. Yang dapat dilakukan adalah bagaimana konflik tersebut harus dikelola (managed), dikendalikan (controlled), dan diselesaikan (settled) secara bersama dengan bijak dan damai, agar tidak berkembang menjadi kekerasan, anarki atau destruktif, menimbulkan disintegrasi atau menghancurkan sendi-sendi hubungan sosial dalam kehidupan masyarakat ${ }^{40}$.

Konflik-konflik yang terjadi dalam masyarakat menurut Nader dan Todd ${ }^{41}$ terjadi melalui tahapan-tahapan: Grievance,yaitu berawal dari munculnya keluhan dari salah satu pihak terhadap pihak yang lain (individu atau kelompok), karena pihak yang mengeluh merasa hak-haknya dilanggar, diperlakukan secara tidak wajar, kasar, dipersalahkan, diinjak harga dirinya, dirusak nama baiknya, dilukai hatinya, dan lain-lain. Kondisi awal ini disebut sebagai tahapan pra-konflik (pre-conflict stage) yang cenderung mengarah kepada konfrontasi yang bersifat monadik (monadic). Pada tahap kedua, apabila kemudian pihak yang lain menunjukan reaksi negatif berupa sikap yang bermusuhan atas munculnya keluhan-keluhan dari pihak pertama, maka kondisi ini akan meningkat eskalasinya menjadi situasi konflik (conflict stage), sehingga konfrontasi antar pihak-pihak berlangsung secara diadik (diadic). Pada tahap ketiga situasinya akan meningkat menjadi sengketa (dispute stage), disini konflik antar pihak-pihak tersebut akan ditunjukan dan dibawa kearena publik (masyarakat) dan kemudian diproses menjadi kasus perselisihan dalam institusi penyelesaian sengketa tertentu dengan melibatkan pihak ketiga. Sifat konfrontasi antar pihak-pihak yang berselisih menjadi triadik (triadic).

Secara umum terjadinya konflik dalam masyarakat bersumber dari persoalanpersoalanseperti:(1)Penguasaan, pemanfaatan dan distribusi sumber daya alam yang menjadi

39 I Nyoman Nurjaya, Pengelolaan Sumber Daya Alam Untuk Menjamin Kemakmuran Rakyat (Jakarta: Badan Pembinaan Hukum Nasional, Kementerian Hukum dan Hak Asasi Manusia RI, 2015). hlm. 73.

40 Ibid.

41 Nader L dan H F Todd Jr (eds), Dispute Processes-Law in Ten Societies, (Columbia: Columbia University Press, 1978), pp. 14-15. 
pendukung kehidupan manusia (natural resource contol and distribution); (2) Ekspansi batas wilayah kehidupan suatu kelompok masyarakat (territoriality expantion); (3) Kegiatan Ekonomi Masyarakat (economic activities); (4) Kepadatan penduduk (density of population) $)^{42}$.

Model-model penyelesaian konflik atau sengketa yang dapat dilakukan oleh masyarakat tergantung pada sistem nilai, norma, politik, ekonomi dan keyakinan sangat mempengaruhi pilihan bentuk institusi dan model-model penyelesaian konflik dalam masyarakat. Institusi penyelesaian konflik yang dikenal masyarakat paling tidak ada 2 macam, yaitu:

1. Institusi penyelesaian konflik yang bersifat tradisional, yang bersumber dari sistem politik dan hukum rakyat dan berlangsung secara tradisional (folk institutions).

2. Institusi penyelesaian sengketa yang dibangun dari sistem politik dan hukum Negara (state institutions) ${ }^{43}$.

Nader dan Todd ${ }^{44}$, memberikan gambaran tentang cara-cara dari pengkaji (ahli) Antropologi Hukum untuk mengatasi atau menyelesaikan keluhan-keluhan atau perasaan tidak diperlakukan secara adil atau sengketa-sengketa, yang berkembang dalam kebudayaan-kebudayaan manusia, sebagai berikut:
(1) Membiarkan saja, atau dalam kata-kata Felstiner (lumping it). Pihak yang merasakan perlakuan yang tidak adil, gagal dalam upaya untuk menekankan tuntutannya.,(2) Mengelak (avoidance), (3) Paksaan atau (coercion), yaitu satu pihak memaksakan pemecahan masalah pada pihak lain, (4) Perundingan (negotiation), dua pihak yang berhadapan merupakan para para pengambil keputusan. (5) Mediasi, (mediation) yaitu pemecahan masalah menurut perantara, (6) Arbitrase, kedua pihak yang bersengketa sepakat untuk meminta perantara pihak ketiga (arbitrator),(7) Peradilan, adjudication.

Dalam praktek penyelesaian sengketa dalam sistem hukum nasional dikenal beberapa bentuk atau cara penyelesaian sengketa yaitu negosiasi, mediasi, pencari fakta, konsiliasi, penilaian ahli, arbitrase, dan litigasi atau berperkara di pengadilan ${ }^{45}$.

Terkait perlindungan hukum terhadap petani, munculnya disvaritas dalam pemanfaatan sumberdaya hutan dan meningkatnya konflik pengelolaan sumberdaya hutan. Implementasi paradigma baru tersebut melahirkan sebuah sistem yang dikenal dengan nama PHBM (Pengelolaan Sumberdaya Hutan Bersama Masyarakat).

Gerakan reformasi menjadi berkah tersendiri bagi para petani untuk menemukan jalan baru penyelesaian sengketa hak atas

42 I Nyoman Nurjaya, op.cit., hlm. 75.

43 I Nyoman Nurjaya, loc.cit., hlm. 77.

44 Nader L dan H F Todd Jr (eds), Dispute Processes-Law in Ten Societies, (Columbia: Columbia University Press, 1978), p. 9.

45 Takdir Rahmadi, op.cit., hlm. 16-21. 
tanah mereka. Para petani mulai mengorganisir diri untuk melawan ketidakadilan yang selama ini diderita. Dibentuklah berbagai organisasi (secara bahasa berarti badan, institusi, lembaga, wadah) atau paguyuban (dari kata guyub, yang artinya akur, kompak, bersatu hati, rukun. Sedang paguyuban atau peguyuban berarti kekerabatan, komunitas atau masyarakat) kaum tani di berbagai tempat di mana sengketa tanah terjadi. Strategi organisasi juga dilakukan oleh para petani yang tinggal di tepian kawasan hutan saat berhadapan dengan Perhutani. Di Blora, para petani yang berseteru dengan Perhutani membentuk kelompok-kelompok tani yang disebut Lembaga Rembug Hutan. Institusi atau organisasi tersebut dalam istilah sosiologi Berger dan Neuhaus disebut sebagai 'mediating structures' (institusi-institusi mediasi) di mana wujud konkretnya merujuk pada lembaga keluarga, ketetanggaan, keagamaan dan juga asosiasi keswadayaan. Institusi mediasi merupakan lembaga-lembaga sosial yang memiliki posisi di antara wilayah kehidupan individu yang bersifat privat dengan kehidupan sosial yang bersifat publik. Dalam kultur politik liberal, institusi mediasi merupakan sarana untuk pemberdayaan individu-individu agar tidak mengalami keterasingan saat menghadapi the bigness atau realitas makro. Realitas sosial yang serba makro ini merupakan ciri utama dari aktivitas lembaga-lembaga modern, seperti korporasi, konglomerasi, birokrasi, partai politik atau organisasi besar lainnya.
Apabila institusi mediasi diakui dan dimanfatkan maksimal dalam pengambilan kebijakan publik khususnya mengenaikan penyelesaian sengketa tanah maka warga akan feeling at home. Berbagai kebijakan dan pengaturan akan lebih bermakna bagi warga. Pendayagunaan institusi mediasi akan menghindarkan kecenderungan pemegang kekuasaan bertindak coercive dan individu juga tidak bersikap anarkis dalam memperjuangkan aspirasi hukumnya. Dengan demikian, kedua belah pihak dapat saling menghormati keinginan masing-masing hingga tercapai suatu model penyelesaian sengketa tanah yang apik. Organisasi, asosiasi, paguyuban atau apapun namanya, memiliki fungsi penting sebagai sarana untuk meraih tujuan. Tujuan merupakan akhir dari tindakan, sedang tindakan itu sendiri adalah alat untuk mencapai tujuan organisasi. Para analisis gerakan sosial mengakui bahwa organisasi merupakan strategi penting untuk memobilisasi partisipasi massa dalam meraih pengakuan hukum atas tanah yang disengketakan. Dengan organisasi, posisi tawar (bargaining position) petani semakin naik sehingga perjuangan mereka akan lebih efektif berjalan. Organisasi tersebut juga berfungsi menyatukan upaya-upaya hukumsosial-politik petani yang terpecah-pecah sehingga rentan gagal. Dengan organisasi, mereka belajar melakukan tindakan secara terencana dan sistematis.

Kesadaran untuk mengorganisasikan diri ini merupakan refleksi dan respon atas 
ketidakadilan dan marjinalisasi yang mereka alami. Strategi perlawanan 'bungkam' selama masa Orde Baru tidak bisa lagi dilanjutkan dan sekarang mereka harus pro-akif menyelesaikan masalahnya, apalagi konstelasi politik telah pasca reformasi. Ciri perlawanan hukum mereka lebih ekpresif, eksplosif, terbuka dan massal. Mengapa demikian, jawaban teoritiknya dapat ditemukan dalam buku Dynamics of Contention. Gerakan sosial hukum terjadi secara kondusif pada masyarakat yang sedang berubah (transition). Dalam situasi transisi, biasanya pertikaian (contention) meningkat karena didukung sumber daya eksternal dan kesempatan politik. Aktor-aktor perlawanan makin leluasa merespon isu, memobilisasi struktur-struktur sosial dan budaya sehingga memungkinkan dilakukannya koordinasi, komunikasi dan mewujudkan komitmen bersama untuk memperjuangkan tuntutannya.

Akses informasi yang terbuka lebar ini merupakan buah dari pengorganisasian yang dilakukan para petani. Secara rutin dan periode mereka mendapat informasi yang dibutuhkan tentang apa saja yang berkaitan dengan tuntutan mereka. Informasi itu bisa datang dari elit-elit internal mereka yang biasanya lebih terdidik dan melek tehadap dunia luar. Dapat pula berasal dari sumbersumber bacaan seperti media massa dan elektronik, selebaran atau buku-buku yang mereka cari sendiri atau diberikan oleh orang lain. Informasi yang lebih kritis umumnya berasal dari aktor dari luar, misalnya aktivis dari lembaga swadaya masyakarat dan pihak lain yang konsen terhadap perjuangan petani.

Komunikasi hukum ini sangat penting untuk kelangsungan dan keberhasilan tuntutan mereka. Manfaat yang diharapkan dari jaringan dan komunikasi hukum dengan banyak pihak, antara lain adalah; pertama, setidaknya mendapat dukungan moral dan simpati atas penderitaan yang dialami oleh para petani dan perjuangan yang sedang berlangsung; kedua, memperoleh bantuan hukum atas sengketa tanah yang sedangkan diselesaikan; ketiga, mendapatkan masukan dan saran bagaimana sebaiknya tersebut diselesaikan; keempat, untuk mendapatkan dukungan dan rekomendasi politik agar sengketa dapat diselesaikan secara menyeluruh; kelima, mendapatkan mediator yang tepat sehingga para pihak mau duduk bersama dan sederajat untuk menyelesaikan masalahnya; keenam, mengkomunikasikan dan men-sharing masalah-masalah hukum yang mereka hadapi.

Komunitas petani hampir selalu menggunakan strategi demontrasi untuk memperjuangkan hak mereka. Ruang demontrasinya sangat luas dan beragam, mulai dari DPRD, Pemerintah Daerah dan sampai Perhutani sebagai pihak yang bermasalah langsung dengan para petani. Jika berhadapan dengan mereka, para petani akan menyampaikan tuntutannya secara mengenai pokok masalah yang disengketakan. Misalnya soal tanah-tanah warga yang diklaim oleh perhutani, ketiadaan akses warga untuk ikut 
memanfaatkan hasil hutan dan sebagainya. Seringkali, demontrasi di hadapan mereka juga menemukan jalan buntu sehingga petani juga mengagendakan tempat-tempat lain untuk berdemo. Pembabatan pohon jati adalah salah satu strategi MDH untuk menuntut haknya. Motifnya adalah merusak atau menebang pohon jati milik Perhutani dan bukan berniat untuk blandong atau mencuri atau menjarah kayu. Aksi ini sering dilakukan sebagai respon terhadap perilaku aparat Perhutani yang dianggap berlebihan kepada warga, terutama di awal reformasi ketika warga kecewa dengan perlakuan Perhutani selama ini. Setelah itu aksi ini telah ditunggangi dengan kepentingan tertentu, seperti motif ekonomi dan melibatkan jaringan yang sistematis dan luas, seperti masyarakat, para cukong atau penadah kayu curian, oknum Perhutani, oknum TNI, oknum Polri dan lain-lain.

Perlawanan menuntut balas biasanya muncul ketika mereka merasa diperlakukan tidak sepantasnya oleh para petugas kehutanan, seperti misalnya mereka dipukuli atau ditembak oleh petugas kehutanan. Perlakuan semacam itu akan dibalas oleh masyarakat dengan berbagai cara seperti misalnya masyarakat akan sengaja merusak tanaman-tanaman jati milik Perhutani, sengaja menebangi pohon-pohon jati atau bahkan mengancam para petugas Perhutani sampai membakar dan merusak berbagai sarana Perhutani yang ada di sekeliling mereka. Strategi ini akhirnya juga mempengaruhi sikap aparat Perhutani dan melembangkan jalan untuk terjadinya dialog.

Dalam paradigma penyelesaian sengketa non-litigasi, lobi bukanlah bagian dari mekanisme penyelesaian sengketa. Istilah lobi lebih menonjol digunakan di arena politik, misalnya ketika keputusan politik gagal disepakati secara bulat atau aklamasi, maka masing-masing partai atau fraksi melakukan lobi kepada pihak yang berseberangan. Jadi, lobi adalah kegiatan di dunia politik yang dimaksudkan untuk mempengaruhi lembaga yang berkuasa, untuk memastikan bahwa pandangan atau kepentingan pribadi atau organisasi yang bersangkutan terwakili dalam pemerintahan. Meskipun lobi tidak dikenal dalam aturan perundang-undangan, namun istilah ini lebih terkenal dan telah menjadi bagian penting dalam proses politik. Yang populer dalam undang-undang adalah musyawarah untuk mufakat dan bukan lobi. Menurut pengertian praktis politisi, musyawarah dan mufakat dapat disamakan artinya dengan lobi, namun dalam bentuk yang berbeda. Jadi lobi adalah turunan dari musyawarah. Jika musyawarah dilakukan secara formal dan transparan, maka lobi dilakukan secara informal dan tertutup. Menurut Priyo Budi Santoso, lobi adalah proses untuk menyamakan pandangan. Oleh karena dilakukan secara informal, terselubung dan tidak terbuka, lobi seringkali dipahami sebagai kegiatan yang tidak selamanya positif. Bisa-bisa saja, keputusan dari lobi bertentangan dengan hasil-hasil musyawarah asal saja ada kompensasi atau imbal-balik 
yang sepadan.

Mediasi merupakan model penyelesaian alternatif sengketa tanah di mana pihak luar yang tidak memihak dan netral dihadirkan untuk ikut membantu pihak-pihak yang bersengketa mendapatkan solusi yang saling menguntungkan. Jika negosiasi mentok dan tidak memperoleh hasil yang memadai oleh sebab masing-masing pihak kokoh dengan argumentasi dan pendiriannya, salah satu pihak atau dua-duanya dapat menempuh jalur mediasi. Pada prinsipnya, mediasi merupakan negosiasi yang melibatkan pihak ketiga yang netral (mediator) yang dapat diterima oleh para pihak yang sedang bersengketa. Secara teoritis, peran mediator sebatas memberikan bantuan substantif, saran-saran dan nasehat, sedang otoritas membuat keputusan tetap pada pihak yang bersengketa.

Pelaksanaan mediasi pada kasus penyelesaian sengketa tanah sangat berbeda dengan model mediasi di pengadilan, di mana sebagian besar mediatornya berasal dari hakim. Sangat berbeda pula dengan mediasi dalam sengketa bisnis. Dalam sengketa tanah yang melibatkan para petani dengan perusahaan perkebunan (sengketa tanah perkebunan) atau Perum Perhutani (sengketan tanah kawasan hutan), para petanilah yang aktif meminta bantuan pihak ketiga (mediator) untuk membantu menyelesaikan masalahnya. Pihak ketiga yang diminta menjadi mediator biasanya kepala daerah (bupati atau gubernur) dan atau Dewan Perwakilan Rakyat Daerah (DPRD). Yang perlu dicatat dan hal ini yang membedakan dengan mediasi di pengadilan atau mediasi singketa bisnis, termasuk berbeda dengan konsep-konsep teoritis adalah; pertama, bahwa kehadiran pihak ketiga itu (mediator) belum tentu disetujui oleh pihak lawan; kedua, pihak ketiga tersebut juga bukan dari kalangan profesional yang memang terdidik atau dididik untuk menjadi mediator; ketiga, netralitas atau ketidakberpihakan (impartial) dipertanyakan oleh karena keduanya merupakan lembaga politik.

Penunjukan mediator dari kalangan yang kuat dan otoritatif (seperti kepala daerah atau anggota dewan) sehingga dapat mempengaruhi hasil-hasil perundingan, sungguhpun memiliki legitimasi teoritis dari Moore dengan authoritative mediatornya dalam prakteknya ada tujuan-tujuan lain yang perlu mendapat perhatian. Rupanya menunjuk mediator yang otoritatif merupakan strategi para petani agar pihak lawan mau duduk bersama menyelesaikan masalahnya. Sedang menurut para petani, pihak-pihak yang dapat memaksa perusahaan perkebunan dan atau Perhutani mau duduk berunding adalah pihak pemerintah (kepala daerah) dan kekuatan politik (DPRD). Oleh karena umumnya perusahaan sangat sulit untuk merealisasikan hasil-hasil kesekapatan, dengan penunjukan mediator yang otoritatif maka para pihak diikat agar tidak main-main dan segera melaksanakan kesepakatan. Selain itu, terutama para petani sangat berharap adanya tindak lanjut dari pemerintah oleh karena 
itulah pemerintah juga dilibatkan sejak awal sebagai mediator bila memang penyelesaian sengketanya harus ditetapkan dan dilegalkan dengan putusan pemerintah. Misalnya, pihak pemerintah dapat memaksa BPN untuk segera menerbitkan sertipikat atas nama warga.

Perhutani juga menawarkan mekanisme penyelesaian berupa program Pengelolaan HutanBersamaMasyarakat(PHBM/Managing Forest with Community), yang pada era Orde Baru disebut kerja sama model tumpangsari. PHBM merupakan sistem pengelolaan sumber daya hutan yang dilakukan oleh perusahaan (perum Perhutani) dan masyarakat kawasan hutan dengan semangat berbagi agar manfaat sumber daya hutan dapat terwujud secara optimal. Semangat yang dibangun oleh Perum Perhutani dengan PHBM ini adalah kemauan (willingness) masyarakat sekitar hutan dan pihak-pihak lain yang tertarik untuk berbagi dalam pengelolaan sumber daya hutan berdasarkan prinsip-prinsip keseimbangankeberlanjutan, kesesuaian dan keselarasan dalam pengelolaan hutan.

Perum Perhutani merumuskan prinsipprinsip dasar PHBM adalah sebagai berikut: a) jujur dan demokratis (fairness and democracy); b) keterbukaan dan kebersamaan (openness and togetherness); c) mau belajar dan saling memahami (lesson learned and understanding on each other); d) kejelasan antara hak dan kewajiban (clarity of right and duty); e) pemberdayaan ekonomi demokrasi (empowerment of democracy economic); f) kerjasama lembaga (institution cooperativeness); g) perencanaan partisipatif (participation planning); h) sederhana dalam sistem dan prosedur (simplicity in system and procedure); i) perusahaan sebagai fasilitator; j) kesesuaian antara pengelolaan dan karakteristik area.

PHBM sebenarnya adalah pelaksanaan dari amanat Pasal 30 UU No. 41 Tahun 1999 tentang Kehutanan yang berbunyi: dalam rangka pemberdayaan ekonomi masyarakat,setiap badan usaha milik negara, badan usaha milik daerah dan badan usaha milik swasta Indonesia yang memperoleh izin usaha pemanfaatan jasa lingkungan, pemanfaatan hasil industri hutan kayu diwajibkan bekerja sama dengan koperasi masyarakat setempat

\section{Simpulan}

1. Petani tidak diperbolehkan menggarap tanah milik perhutani karena dianggap oleh Perhutani itu adalah Tanah Negara, padahal secara hukum berdasarkan Peraturan Pemerintah Nomor 11 tahun 2010 Penertiban Dan Pendayagunaan Tanah Terlantar apabila tanah yang dikuasai oleh Perhutani tersebut ditelantarkan maka akan menjadi tanah Negara bebas yang tidak mempunyai alas hak. Hal ini dianggap oleh petani bahwa Perhutani juga dianggap tidak memiliki hak atas tanah itu sehingga para petani menggarap tanah tersebut. Hal inilah yang mengakibatkan konflik yang harus diselesaikan oleh Negara yang dalam 
hal ini diwakili oleh Badan Pertanahan Nasional harus menyelesaikan masalah ini agar tidak terjadi konflik yang dapat mengakibatkan korban jiwa dan materiil.

2. Bentuk perlindungan hukum terhadap Petani yang menggarap tanah negara yang dikuasai oleh Perhutani adalah melalui perlindungan hukum preventif melalui pemberian hak atas tanah terhadap tanah yang dikuasai oleh Perhutani tersebut tetapi ditelantarkan oleh Perhutani. Tanah tersebut diberikan kepada petani melalui program redistribusi tanah. Sedangkan bentuk perlindungan hukum secara represif, pihak-pihak yang berkonflik dapat dimediasi melalui jalur non litigasi dengan cara negoisasi agar pihak petani dan perhutani tidak berkonflik secara horizontal lagi.

\section{DAFTAR PUSTAKA}

\section{Buku}

Bohannan, Paul. Dalam pengantar Buku Law \& Warfare; Studies in The Antropology of Conflict. Austin and London: University of Texas Press, 1980.

Dahrendorf, Ralf. Konflik dan Konflik dalam Masyarakat Industri Sebuah AnalisaKritik. Diterjemahkan oleh Ali Mandan dari karya asli Class and Class Conflict in Industrial Society. Jakarta: Rajawali, 1968.

Garner, B.A. Black's Law Dictionary. (Eighth ed.). Cambridge: West a Thomson Business, 2004.

Haar, Ter. Asa-asas dan Susunan Hukum Adat (Beginselen En Stelsel Van Het Adatrecht). Terjemahan Soebakti Poesponoto. Jakarta: Pradnya Paramita, 1985.

JA., Noertjahyo. Dari Ladang Sampai Kabinet, Menggugat Nasib Petani.
Jakarta: Buku Kompas, 2005.

Lembaga Penelitian Institut Pertanian Bogor. Sistem Pengelolaan Hutan Rakyat. Bogor: Lembaga Penelitian Institut Pertanian Bogor, 1990.

L, Nader dan H F Todd Jr (eds). Dispute Processes-Law in Ten Societies. Columbia: Columbia University Press, 1978.

Nurjaya, I Nyoman. Pengelolaan Sumber Daya Alam Untuk Menjamin Kemakmuran Rakyat. Jakarta: Badan Pembinaan Hukum Nasional, Kementerian Hukum dan Hak Asasi Manusia RI, 2015.

Rahmadi, Takdir. Mediasi; Penyelesaian Sengketa Melalui Pendekatan Mufakat. Jakarta: RadjaGrafindo Persada, 2010. Ritzer, George. Teori Sosiologi dari Sosiologi Klasik sampai Perkembangan Terakhir Postmoder. Yogyakarta: Pustaka Pelajar, 2012. 
Soepomo. Bab-bab Tentang Hukum Adat. Jakarta: Balai Pustaka, 1996.

Wijaya, Gunawan. Alternatif Penyelesaian Sengketa. Jakarta: RadjaGrafindo Persada. 2001, hlm. 5.

Zaidun. M. Mekanisme Alternatif Penyelesaian Sengketa (MAPS). Dalam Bahan Ajar Penyelesaian Sengketa Alternatif(PSA) Universitas Airlangga. Surabaya: Fakultas Hukum Universitas Airlangga, 2004.

\section{Naskah Internet}

Jatengheadline. "Perhutani Pati Tutup Mata Petani Menderita". www. Jatengheadline.com. Diakses 12 Maret 2016.
Kompas online. "Tamrin dan Istri Minta Maaf". www.kompas.com/. Diakses, 22 Januari 2011.

Meliala, Adrianus. "Penyelesaian Sengketa Alternatif; Posisi dan Potensinya di Indonesia". www.adrianusmeliala. co.id. Diakses 10 Desember2015.

Organic HCS. "Sekilas Definisi dan Konsep, Petani dan Pertanian", https:// organichcs.com/2014/01/10/sekilasdefinisi-konsep-petani-dan-pertanian/. Diakses 9 Desember 2015.

Vja Ambon. "Mekanisme Penyelesaian Sengketa Informal di Kabupaten Buru, Kota Ambon dan Kabupaten Maluku Tengah”. Diakses 18 Desember 2015. 